\title{
A miniaturised and simplified technique for typing and subtyping herpes simplex virus
}

\author{
JM DARVILLE \\ From the University of Bristol Medical School, Department of Virology, Bristol Royal Infirmary, \\ Marlborough Street, Bristol, BS2 $8 H W$
}

SUMMARY A miniaturised, simplified and rapid method for typing and subtyping herpes simplex virus by restriction enzyme analysis of radioactively labelled DNA is described. This method requires far less label than those described previously, giving advantages in both cost and safety and therefore in its suitability for use in a routine laboratory. It produces results indistinguishable from those obtained by the parent method.

Although the typing of herpes simplex virus (HSV) isolates brings no immediate benefit to the patient it is nonetheless a useful test to perform in certain circumstances. For example, recent surveys have demonstrated differences from the traditional orofacial or genital distribution of the two types of the virus, ${ }^{1}$ suggesting that epidemiological patterns are changing. Furthermore, typing might aid the decision on appropriate antiviral chemotherapy (since for example HSV type 1 is more sensitive than type 2 to a range of antiherpes agents ${ }^{2}$ ), although viral sensitivity testing may prove more fruitful.

However, there is no doubt about the value of characterising the intratypic variants of the virus. The ability to identify different strains has obvious applications in epidemiology, such as contact tracing in genital herpes and in analysing apparently linked hospital cases of HSV infection. Furthermore and more speculatively, such detailed analysis might yield information on particular strains being linked with more severe disease, greater transmissibility, increased frequency of recurrent disease, or with particular syndromes such as herpes encephalitis.

It was decided to introduce into this laboratory a simple and fast method for typing and subtyping HSV in order to analyse selected clinical isolates and also in order to perform experiments of a more fundamental scientific nature on the genome of the virus.

The older methods of typing such as plaque morphology, ${ }^{3}$ differential neutralisation, ${ }^{4}$ immunoperoxidase staining, ${ }^{5}$ DNA density analysis, ${ }^{6}$ guanine plus cytosine content ${ }^{7}$ and the formation of intranuclear tubular structures ${ }^{8}$ are either tedious to perform or

Accepted for publication 17 March 1983 subjective or both, and in any case only differentiate the types of the virus. The analysis of viral structural polypeptides ${ }^{9}$ permits finer differentiation but is still fairly laborious. Therefore, it was decided to use restriction enzyme analysis of the viral DNA. ${ }^{10}$ Rather than use an ethidium bromide staining technique, the method of analysing radiolabelled DNA as described by Lonsdale ${ }^{11}$ was chosen since it uses smaller viral cultures and requires less purification of the DNA. This method worked well but proved to be rather wasteful of materials since it yielded much more labelled DNA than was needed for restriction analysis by a limited battery of enzymes. Therefore, for routine use, a more suitable scaled down method having greater economy and radiological safety was developed from the original method.

\section{Material and methods}

\section{VIRUSES}

HSV standard type strains $17 \mathrm{syn}^{+}$SV (type 1) and HG 52 (type 2) were kindly provided by Mr J Lang of the Institute of Virology, Glasgow. The Bristol standard strains of SC 16 (type 1) and AR 15 (type $2),{ }^{12}$ had been typed by plaque morphology in BHK21 cell cultures, by cross-neutralisation and by the presence or absence of intranuclear tubular structures. A large number of HSV isolates was obtained in this laboratory from clinical specimens.

\section{LABELLING OF VIRAL DNA}

Aliquots of $10^{4}$ BHK21 C13 cells (Flow Laboratories Ltd) in $0.1 \mathrm{ml}$ Glasgow Modified Eagles Medium (Flow) supplemented with $10 \%$ Tryptose phosphate broth (Flow), $2 \mathrm{mmol} / \mathrm{l}$ L-glutamine (Flow) and 10\% fetal calf serum are 
seeded per well in 96 well microculture trays (Linbro) which are then incubated at $35^{\circ} \mathrm{C}$ in a humidified $\mathrm{CO}_{2}$ incubator. After three days the cells, now confluent at approximately $10^{5}$ per well, are changed to Eagles Minimum Essential Medium supplemented with $2 \mathrm{mmol} / \mathrm{l} \mathrm{L}$-glutamine and $1 \%$ fetal calf serum but without phosphate (phosphate free medium). Alternatively, $2 \times 10^{4}$ cells may be seeded to be confluent after two days, but attempts to seed for "next day confluence" result in clumping and peeling of the cells. One day later the phosphate free medium is removed and the cells are infected with $10 \mu \mathrm{l}$ virus (undiluted supernatant of frozen and thawed virus culture showing complete cytopathic effect (CPE)). After one hour $50 \mu \mathrm{l}$ phosphate free medium is added and the plates incubated for a further two hours. The medium is then removed and the monolayers washed once in phosphate free medium before adding 50-75 $\mu$ l phosphate free medium containing 5-7.5 $\mu \mathrm{Ci}^{32} \mathrm{P}$ (orthophosphate in dilute $\mathrm{HCl}$, Amersham). The CPE is usually about $75 \%$ after $24 \mathrm{~h}$, but the yield of labelled DNA is higher if the cultures are left until the CPE becomes total (approx. $40 \mathrm{~h}$ ). If the inoculum is of low titre and total CPE takes longer than three days, yields of DNA are again lower.

\section{HARVESTING OF LABELLED DNA}

Fifty to $75 \mu \mathrm{l} 5 \%$ (wt/vol) sodium dodecyl sulphate is added to each well. The contents are mixed with a tip on a 50-250 $\mu$ l Finnpipette before being transferred to a $0.4 \mathrm{ml}$ micro-centrifuge tube (Sarstedt). One hundred to $150 \mu$ l phenol (chromatograph:' grade, BDH) saturated with $20 \mathrm{mmol} / \mathrm{l}$ Tris, 75 $\mathrm{mmol} / 1 \mathrm{NaCl}$ and $50 \mathrm{mmol} / \mathrm{l}$ EDTA is added to each tube which is then capped carefully and shaken vigorously. After standing in ice for $10 \mathrm{~min}$ the tubes are centrifuged for $3 \mathrm{~min}$ at $15600 \mathrm{~g}$ in a microcentrifuge (Eppendorf). The aqueous phase is transferred to a $5 \mathrm{ml}$ plastic centrifuge tube (Sarstedt) with a 50-250 $\mu$ l Finnpipette, an easy procedure since the interface between the aqueous and phenolic phases is not readily disturbed in the thin microcentrifuge tube. After adding two volumes of absolute ethanol the tube is capped and the contents well mixed before being centrifuged for $3 \mathrm{~min}$ at $2500 \mathrm{~g}$ in a bench centrifuge. The ethanol is poured from the tubes which are drained by inversion and finally dried with a sterile swab (avoiding the bottom of the tube). Deionised water $(170 \mu \mathrm{l})$ containing $50 \mu \mathrm{g} / \mathrm{ml}$ RNA-ase $A$ and 250 units $/ \mathrm{ml}$ RNA-ase $T_{1}$ (Sigma) (boiled for $10 \mathrm{~min}$ ) is added and the DNA redissolved by mixing for two hours on an orbital shaker at $100 \mathrm{rpm}$ and $37^{\circ} \mathrm{C}$. The precipitation and redissolving of the DNA can be performed in:0.6 microcentrifuge tubes (Sarstedt), but this leads to difficulties in mixing the aqueous phase with the ethanol, in removing all the ethanol and in redissolving the DNA. Occasionally it may also lead to radioactive contamination of the microcentrifuge.

The ${ }^{32} \mathrm{P}$ content of the DNA solutions is estimated by holding the tubes next to the GM tube of a Mini-Monitor contamination meter (MiniInstruments Ltd), giving a value in counts per second (cps). If an accurate measurement of ${ }^{32} \mathrm{P}$ incorporation is required then $10 \mu \mathrm{l}$ of the DNA solution is applied to a $2 \mathrm{~cm}$ diameter filter paper disc (Whatman No 1). After drying in air $\left(37^{\circ} \mathrm{C}\right)$ the discs are washed twice in cold 5\% trichloroacetic acid and once each in methylated spirits and acetone before being dried and transferred to scintillation vials containing $10 \mathrm{ml} 0.56 \%$ butyl-P B D (KochLight) in toluene. The amount of RNA-ase resistant acid precipitable label is then measured in a scintillation counter and recorded as kilocounts per minute (kcpm).

\section{RESTRICTION ENZYME CLEAVAGE OF DNA}

Restriction enzymes used were Bst I (isoschizomer of Bam HI), Eco RI (Cambridge Biotechnology Laboratories), Pvu II and Kpn I (Bethesda Research Laboratories).

Restriction enzyme digest reaction mixtures are set up in round well microtitre plates as follows. Forty $\mu \mathrm{l}$ DNA solution and $2 \mu \mathrm{l}$ restriction enzyme (ie 2 units except KpnI which is 5 units) are made up to a final volume of $50 \mu \mathrm{l}$ containing $6 \mathrm{mmol} / \mathrm{l}$ Tris $\mathrm{HCl}(\mathrm{pH} 7.5), 6 \mathrm{mmol} / \mathrm{l} \mathrm{MgCl}_{2}, 6 \mathrm{mmol} / \mathrm{l}$ $\beta$-mercaptoethanol and $800 \mu \mathrm{g} / \mathrm{ml}$ nuclease free bovine serum albumin. Alternatively, if incorporation has been measured by scintillation counter, the volume of DNA solution is adjusted to standardise the amount of label (ideally $30-50 \mathrm{kcpm}$ ) in the digests, which are made to volume with sterile deionised water.

The plates are sealed and after $3-4 \mathrm{~h}$ incubation at $37^{\circ} \mathrm{C} 5 \mu \mathrm{l}$ "stop mix" per well (10\% Ficoll 400 in $100 \mathrm{mmol} / \mathrm{l}$ EDTA containing bromophenol blue) is added and mixed by swirling. The digests are then analysed by overnight horizontal agarose $(0 \cdot 6-1 \%)$ gel electrophoresis at $2 \mathrm{~V} / \mathrm{cm}$ in $36 \mathrm{mmol} / \mathrm{l}$ Tris, 30 $\mathrm{mmol} / / \mathrm{NaH}_{2} \mathrm{PO}_{4}$ and $0.9 \mathrm{mmol} / \mathrm{l}$ EDTA (pH 8.5). The plates are air dried $\left(80^{\circ} \mathrm{C}\right)$. Kodirex $x$-ray film is exposed to the plates using intensifier screen enhancement overnight at $-70^{\circ} \mathrm{C}$, and is then processed manually.

\section{Results}

CONSISTENCY OF DNA RADIOLABELLING

In ene experiment the estimates of ${ }^{32} \mathrm{P}$ content of $\frac{\Omega}{\overparen{D}}$ DNA solutions prepared from cultures of 12 differ- 
ent genital isolates of HSV were $150,300,300,300$, $200,400,150,30,200,200,200$ and $300 \mathrm{cps}$. When the same solutions were measured by scintillation counter the values were $7,10,7,8,5,9,3,0 \cdot 2,6,7$, 8 and $10 \mathrm{kcpm}$. Similarly, in another experiment analysing a single strain of HSV type 1 (SC 16) reisolated during acute primary infection of the ears of 10 mice, ${ }^{12}$ the measurements were $100(3), 100$ (6), 150 (5), 150 (7), 150 (4), 200 (4), 100 (6), 150 (6), $150(5)$ and $100(4) \mathrm{cps}(\mathrm{kcpm})$. Thus there is no great variation in the yield of labelled DNA from cultures processed in the same way at the same time whichever measuring system is used and although the two do not fully correlate both picked up the culture with poor incorporation (30 cps $/ 0.2 \mathrm{kcpm})$. It is shown later that the yield variation seen does not markedly affect band density and all profiles shown here were obtained by the restriction of fixed volumes of DNA solutions.

Figure 1 is an autoradiographic profile of the DNAs from the four standard strains of HSV and from three clinical isolates prepared by the method described above and digested by the enzyme Bst I. It shows the markedly different cleavage patterns of types 1 and 2 and the similarities of the patterns within each type. Furthermore, it also clearly demonstrates the differences between cleavage patterns of isolates of the same type, with the exception of tracks 6 and 7 (identical except where arrowed) which are isolates taken at different times from different sites on the same patient. These results are indistinguishable from those obtained with the same viruses analysed by the original method.

Figures 2 and 3 , which are profiles of six clinical isolates from patients with genital herpes demonstrate that the micromethod yields sufficient labelled DNA for analysis by at least four enzymes. These figures are derived from digests of the first six DNA solutions listed in the first experiment above and little variation in the density of the tracks is evident. Although only a few comparative tests of this kind are reported here, it does appear that the omission of scintillation counting and the analysis of fixed volumes of DNA solution are justifiable in routine analysis. Of the six isolates from cases of genital herpes, one (tracks 5 and 11), is type 1 and the other five are type 2 . The type 2 isolates are clearly distinguishable from each other except for the first two which are primary and recurrent isolates taken five months apart from the same patient. The patterns for these two isolates are indistinguishable except where arrowed in the Bst I tracks.

\section{Discussion}

The attraction of the method described here lies in

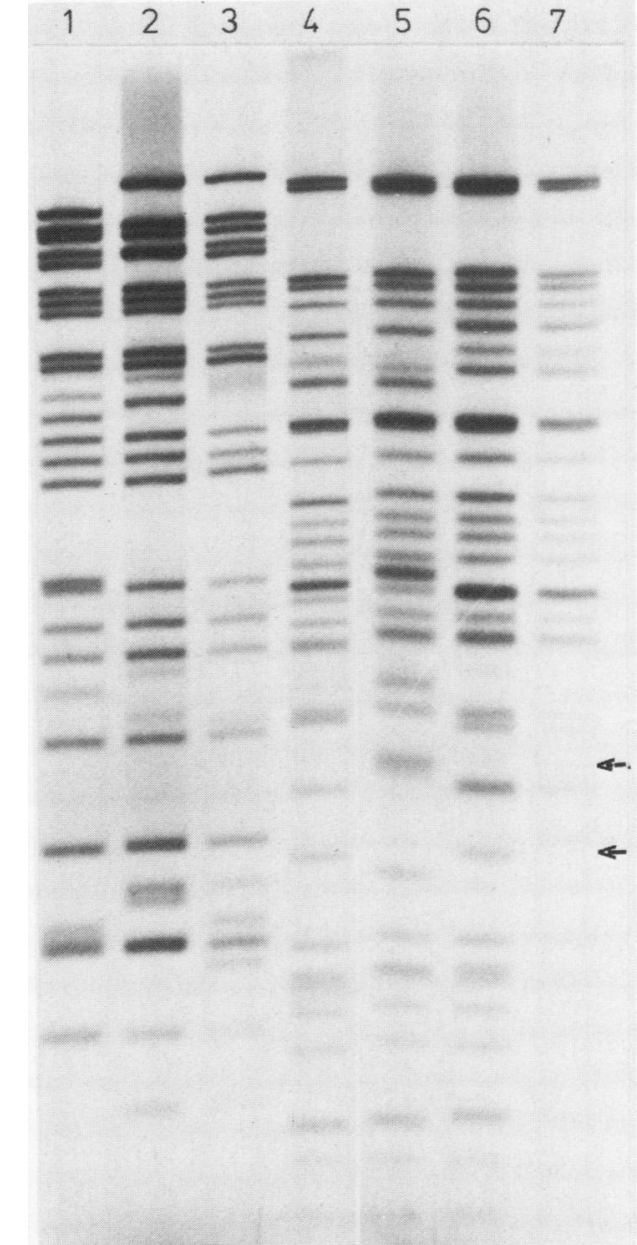

Fig. 1 Bst I restriction endonuclease digest patterns of $H S V 1$ (track 1, SC 16; 2, clinical isolate; 3, 17 syn $^{+}$SV) and HSV 2 (track 4, AR 15; 5, HG 52; 6 and 7, clinical isolates).

its simplification and in its miniaturisation, which potentially allows the preparation of 96 cultures for analysis at the cost of a single microtray. A particular technical advantage is that when using the thin microtubes it is much easier to separate the phases during the phenol extraction without disturbing the interface than it is with the larger tubes of the parent method. The omission of the scintillation count saves time and materials, and although it does not affect the results it must be remembered that the contamination meter counts RNA-ase sensitive and non-acid precipitable activity as well as incorporated label. A possible objection to the analysis of fixed volumes of uncounted DNA is that too much labelled DNA might be added, but in practice it is found 


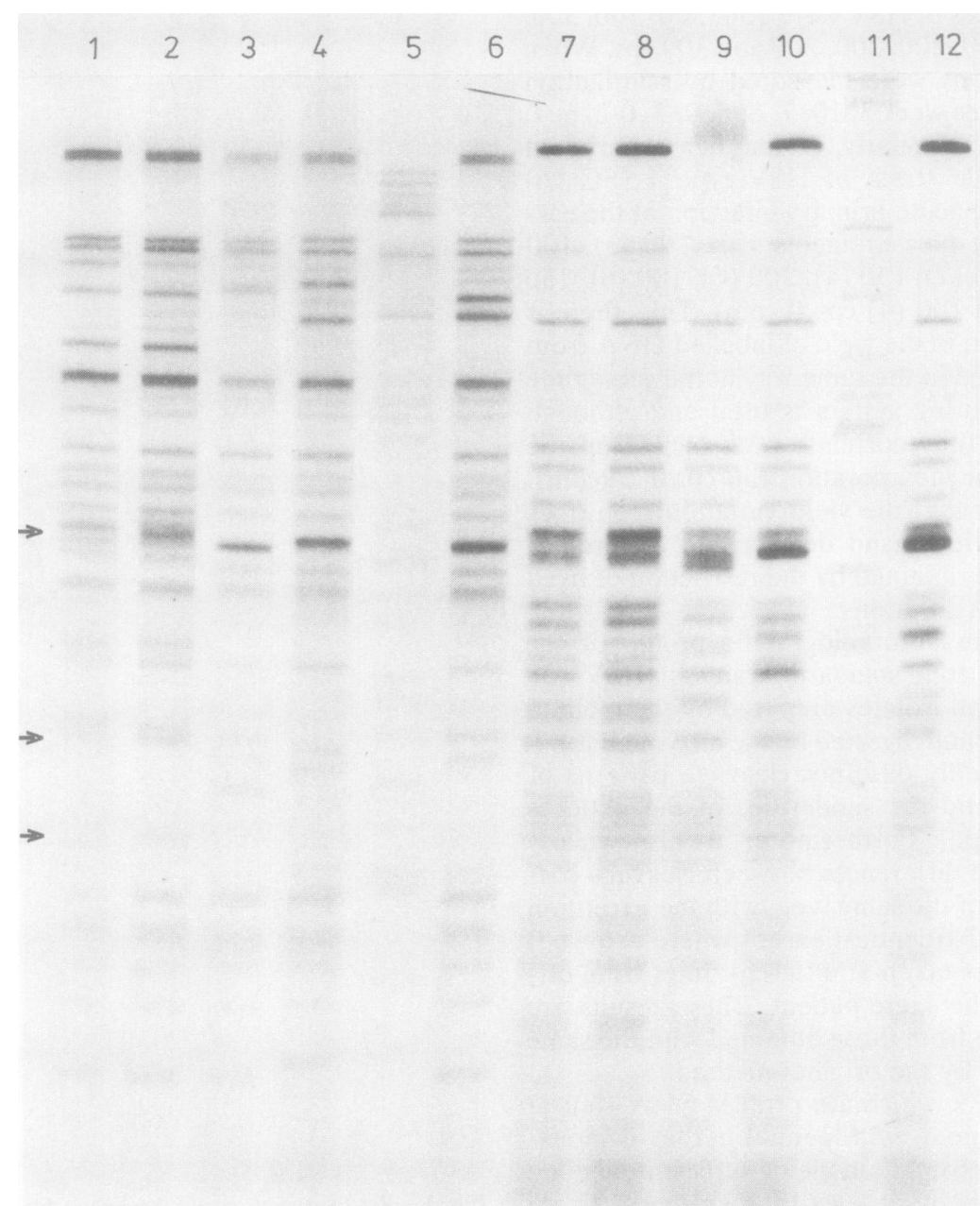

Fig. 2 Bst I (tracks 1-6) and Pvu II (7-12) restriction endonuclease digest patterns of six isolates of HSV from genital herpes.

that the small amount of ${ }^{32} \mathrm{P}$ used precludes the achievement of such high levels of incorporation, and the overloading of tracks has only occurred when the DNA has been incompletely redissolved. Simplification and the use of approximately one tenth of the amount of reagents cuts the time and the cost of typing and means that more isolates can be typed for the same effort and expenditure and without expensive apparatus, bringing typing more truly within the reach of the routine laboratory. In addition, the use of much less ${ }^{32} \mathrm{P}$ reduces the radiological hazard.

All viruses tested produced total or near-total CPE with adequate label incorporation two to three days after inoculation of the BHK cells with $10 \mu \mathrm{l}$ medium from original isolates showing 3 or $4+$ CPE. However, when analysing slow growing viruses (such as low yielding or genetically engineered strains) the micro-method might yield insufficient labelled DNA in which case it would be better to use the macromethod as described by Lonsdale. ${ }^{11}$

Any one enzyme clearly differentiates type 1 from type 2 and if this is the only requirement then the method could be simplified further still, for example by using just one or two enzymes chosen for cheapness and stability. The best enzymes for demonstrating fine intratypic differences are those for which the viral DNA has many cleavage sites, ${ }^{14}$ a requirement fulfilled in this case by Bst I and Pvu II.

The value in demonstrating intratypic variants lies 


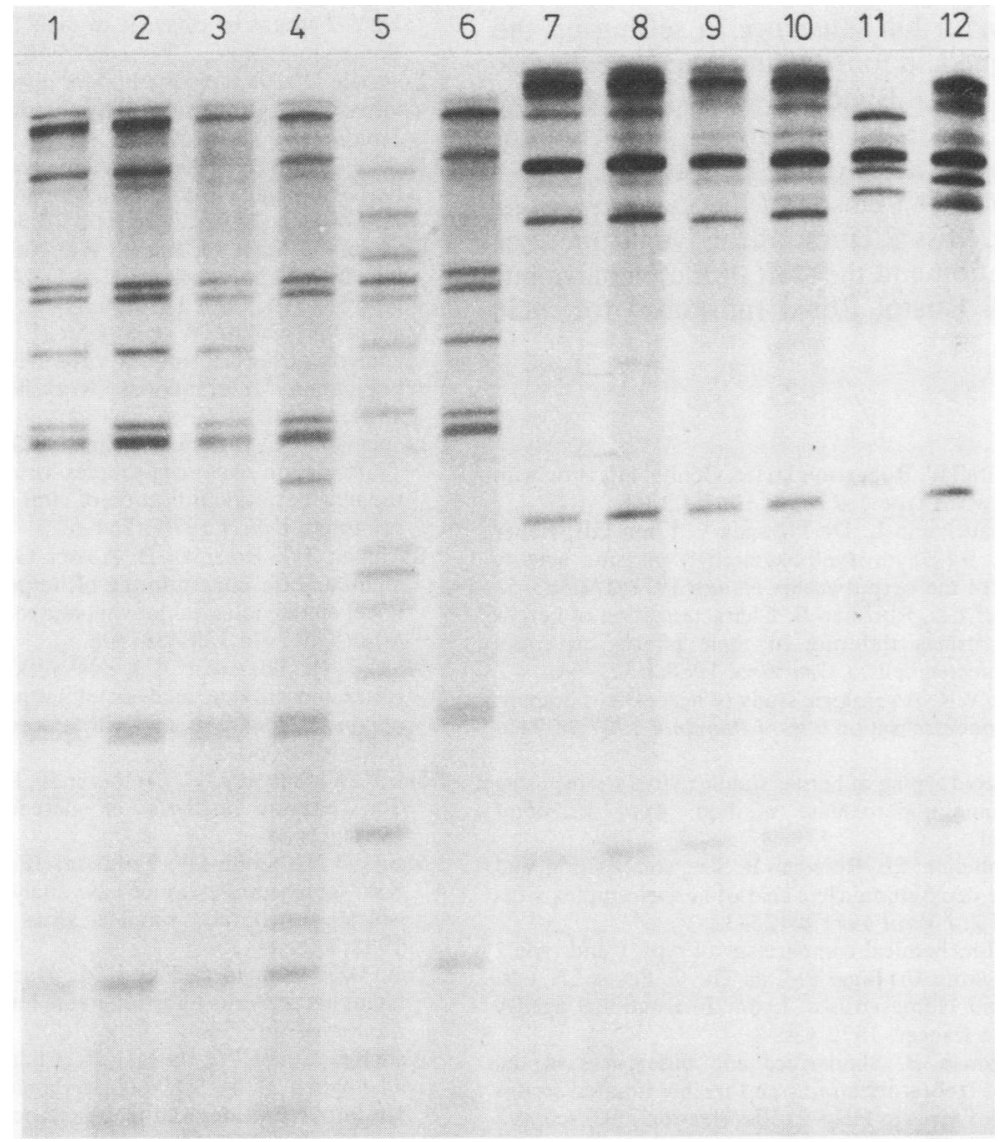

Fig. 3 Kpn I (tracks 1-6) and Eco RI (7-12) restriction endonuclease digest patterns of six isolates of HSV from genital herpes.

in the application to HSV epidemiology ${ }^{15-17}$ since the variants show cleavage pattern stability. ${ }^{16}$ Recently it has been shown that sequential isolates from one individual may show variation ${ }^{18} 19$ and caution has been urged in the interpretation of cleavage analysis patterns. In this study, successive isolates from the same patients showed similar variation (Figs. 1 and 2; and unpublished observations) but the differences are far less than those seen between unrelated isolates. It seems that the minor changes or drifts that occur with time, while most interesting in themselves, do not obscure the close relation between successive isolates. Furthermore, the technique reported here carried out blind has correctly differentiated a pair and a triplet of isolates from different sites within the same individuals from several unrelated isolates, ${ }^{20}$ and has shown isolates obtained from two related individuals to be virtually indistinguishable (unpublished observation).

This simplified procedure has also been used to analyse adenovirus DNA (unpublished observations). Should it prove suitable for analysing a range of adenoviruses then it might supplement conventional serotyping, for example to show possible variants within serotypes. ${ }^{21}$

In conclusion, the method described here should bring the application of restriction enzyme technology to the typing of some DNA viruses within the reach of more routine virus laboratories.

This work was supported by a grant from the Research Committee of the Bristol and Weston Health District.

I wish to thank Mr J Lang of the Institute of Vir- 
ology, Glasgow for his assistance in setting up the original technique and for helpful advice and discussion, and Dr WA Blyth, of the Microbiology Department, University of Bristol, for helpful advice in the preparation of the manuscript.

I also thank Mrs Wilkinson of the Department of Radiodiagnosis, Miss E Hurst of the Department of Medical Illustration and the staff of the Department of Virology (all Bristol Royal Infirmary) for their assistance.

\section{References}

' Peutherer JF, Smith IW, Robertson DHH. Genital infection with herpes simplex virus type 1.J Infect 1982;4:33-5.

${ }^{2}$ Schaeffer HJ, Beauchamp L, De Miranda P, Elion GB, Bauer DJ, Collins P. 9-(2-hydroxyethoxymethyl) guanine activity against viruses of the herpes group. Nature 1978;272:583-5.

${ }^{3}$ Ejercito PM, Kieff ED, Roizman B. Characterization of herpes simplex virus strains differing in their effects on social behaviour of infected cells. J Gen Virol 1968;2:357-64.

${ }^{4}$ Pauls FP, Dowdle WR. A serologic study of herpesvirus hominis strains by microneutralisation tests. J Immunol 1967;98:9417.

${ }^{5}$ Benjamin DR. Rapid typing of herpes simplex virus strains using the indirect immunoperoxidase method. Appl Microbiol 1974;28:568-71.

${ }^{6}$ Kieff ED, Bachenheimer SL, Roizman B. Size, composition, and structure of the deoxyribonucleic acid of herpes simplex virus subtypes 1 and 2.J Virol 1971;8:125-32.

${ }^{7}$ Halliburton IW. Biochemical comparisons of type 1 and type 2 herpes simplex virus. In: Biggs PM, de The G, Payne LN, eds. Oncogenesis and Herpesviruses. Lyon: International agency for Research on Cancer, 1972:432-8.

8 Schwartz J, Roizman B. Similarities and differences in the development of laboratory strains and freshly isolated strains of herpes simplex virus in HEp-2 cells: electron microscopy. $J$ Virol 1969;4:879-99.

9 Pereira L, Cassai E, Honess RW, Roizman B, Terni M, Nahmias A. Variability in the structural polypeptides of herpes simplex virus strains: potential application in molecular epidemiology. Infect Immun 1976;13:211-20.

${ }^{10}$ Skare J, Summers WP, Summers WC. Structure and function of herpesvirus genomes 1 . Comparison of five HSV-1 and two
HSV-2 strains by cleavage of their DNA with Eco RI restriction endonuclease. $J$ Virol 1975;15:726-32.

"Lonsdale DM. A rapid method for distinguishing herpes-simplex virus type 1 from type 2 by restriction enzyme-technology. Lancet 1979;i:849-52.

${ }^{12}$ Hill TJ, Field HJ, Blyth WA. Acute and recurrent infection with herpes simplex virus: a model for studying latency and recurrent disease. J Gen Virol 1975;28:341-53.

${ }^{13}$ Graham FL, Smiley J, Russell WC, Nairn R. Characteristics of a human cell line transformed by DNA from human adenovirus type 5. J Gen Virol 1977;36:59-72.

${ }^{14}$ Maitland NJ, Smith IW, Peutherer JF. Restriction endonuclease analysis of herpes simplex virus DNA variation in a limited population. International Workshop on Herpes viruses, 1981:22.

${ }^{15}$ Linnemann CC, Light IJ, Buchman TG, Ballard JL, Roizman B. Transmission of herpes-simplex-virus type 1 in a nursery for the new born: identification of viral isolates by DNA "fingerprinting". Lancet 1978;i:964-6.

${ }^{16}$ Buchman TG, Roizman B, Adams G, Stover BH. Restriction endonuclease fingerprinting of herpes simplex virus DNA: a novel epidemiological tool applied to a nosocomial outbreak. $J$ Infect Dis 1978;138:488-498.

17 Whitley R, Lakeman AD, Nahmias A, Roizman B. DNA restriction-enzyme analysis of herpes simplex virus isolates obtained from patients with encephalitis. $N$ Engl $J$ Med 1982;307:1060-2.

18 Smith IW, Maitland NJ, Peutherer JF, Robertson DHH. Restriction enzyme analysis of herpesvirus-2 DNA. Lancet $1981 ; \mathrm{ii}: 1424$

${ }^{19}$ Maitland NJ, Smith IW, Peutherer JF, Robertson DHH, Jones KW. Restriction endonuclease analysis of DNA from genital isolates of herpes simplex virus type 2 . Infect Immun 1982;38:834-42.

${ }^{20}$ Tullo AB, Shimeld C, Easty DL, Darville JM. Distribution of latent herpes virus infection in the human trigeminal ganglion. Lancet 1983;i:353.

${ }^{21}$ Wadell G, Sundell G, de Jong JC. Characterization of candidate adenovirus 37 by SDS-polyacrylamide gel electrophoresis of virion polypeptides and DNA restriction site mapping. J Med Virol 1981;7:119-25.

Requests for reprints to: Dr JM Darville, Department of Virology, Bristol Royal Infirmary, Marlborough Street, Bristol BS2 8HW, England. 